Challenging the teaching of geographies of exclusion - the potential of geocapabilities for a transcultural approach in Australian and English schools

6857 words + Abstract (200) 


\section{Abstract (200)}

This expository paper critically examines the value of school geography in social debates that have a direct significance for the lives of young people. Migration is chosen as a focus, both because it is a defining feature of everyday life and the world we live in, and an area of research and debate in the discipline of geography. We draw on two national contexts, those of Australia and England, and illustrative examples from the authors' research, to discuss how social change through migration is explored, expressed and represented in geography education by the national curriculum of each country. This occurs through two particular lenses, geocapabilities and transculturalism, which are presented as potential transformative strategies for ensuring that geographical teaching of such issues remains pertinent to the lives and futures of the young people in the classroom. In doing so, the paper seeks to critically consider the omnipresent socio-political agendas and landscapes of compulsory schooling in each nation that influence the construction of geography education, using the context of migration as a defining social dimension of contemporary global society. The paper concludes by arguing that geography teachers and educators should actively consider the use of a geocapabilities and/or transcultural lens when exploring complex social geographies such as migration. In doing so, it is contended that these dual concepts can support and empower young people in their academic and social navigation of the complexities of current society.

\section{Keywords}

geography education

powerful geography

geocapabilities

transculturalism

migration 


\section{A Introduction}

'You know how people say that London, or the UK, is really diverse and everyone is accepting. On one hand, this is true, because people start to live with it. But, after a while you start to realize, that some people don't accept. They act like they do, but deep down they don't accept'

Tilly, 13 years, London (Author 3, unpublished, forthcoming)

Tilly's quote reminds us that, even in London, a city often celebrated for its diversity and acceptance, cultural divisions exist. For geography educators, her words invite a question how can school geography help to examine and address geographies of exclusion? In this paper, we offer a possible answer by exploring the potential of two alternative curriculum lenses - 'geocapabilities' and 'transculturalism' - through the junior secondary school geography curriculum in Australia and England. Before explaining the meaning of 'geocapabilities' and 'transculturalism', it is important that we establish how we see curriculum in wider educational purpose, and why this may differ from national educational policies. Conflicting or unclear purposes of school geography are bound up with the problem of how to address the geographies of exclusion.

One of the persistent educational debates in terms of the school curriculum is the 'relevance' of what is being taught to the present and future contexts to pupils. Governments (educational policy makers), teachers, educators and children tend to understand 'relevance' in a geography curriculum differently (Author 2, 2009). 'Relevance' is therefore a problematic term. Consequently, in this paper we prefer to employ the more helpful notion of curriculum 
'significance', drawing from Klafki's (2000) use of the significance of subject content in 'opening up' new ways of seeing, for both the current and future life of the child. Additionally, as we will discuss later, we also see 'powerful knowledge' (Young and Muller, 2010) as being an advantageous concept from which to argue for a 'capabilities' approach to justify the selection of curriculum content.

At the level of the school system, a focus on a pertinent program of learning can be reflected in the disciplinary structure of the curriculum framework being offered; in short, which subjects are deemed to be of such long-term importance to a child's evolving education that they are classified as mandated areas of learning. At the school level, these policy imprimaturs of an approved learning hierarchy are translated into even more fundamental signs of commendation, such as the amount of teaching time allotted to a subject, or whether a subject is nominated as being compulsory (part of the core learning program) or optional. In such a context, the work of a teacher becomes partly one of professional or employment survival, and not just one of educational value. Any attempt to transform a student's learning experience may have to be mediated by the more prosaic reality of ensuring that a teaching subject demonstrates to students that it is 'deserved' of their continued interest because of its significance to their future lives, employment and existence.

Within the broad pantheon of 'Western' styles of educational system, represented in this paper by the cases of Australia and England, the place of Geography as a school subject of universal regard has had a chequered history. It is not within the scope of this paper to provide a deep analysis of the historical situation. However, a few general points highlight the need for geography educators to address this relative uncertainty as a school discipline, and within that endeavour, to bear even more in mind the need for student significance (Butt \& Lambert, 2014). 
In places such as the USA and Canada, the discipline has been subsumed into the amorphous area of social studies education (Semple, 2005). In England, Geography has had a more considered reputation of permanence, whereas, in Australia, as with New Zealand (Morgan, 2014), the existence of the discipline as a school subject has varied over time according to the changing educational philosophies of individual state governments (Biddle, 1999; Bliss, 2006; Author 1, 2015; Conolly, 2000; Hutchinson, 2006).

In line with these concerns, and motivated by calls such as Lambert et al.'s call for geography education to consider the 'role of geography in producing an educated person in this day and age' $(2015$, p. 726$)$, this expository paper is concerned with critically examining the value of school geography in social debates that have a direct significance to the lives of young people such as Tilly, whose thoughts about social cohesion and acceptance opened this paper. In order to do this, the paper draws on two national contexts, those of Australia and England, examining how social change through migration is explored, expressed and represented in geography education by the national curriculum of each country. This will take place through the examples of two particular lenses or perspectives - geocapabilities and transculturalism. These lenses are presented as new and potentially transformative strategies for ensuring that geography teaching, by relating to current social issues, remains significant for the lives and futures of the young people in the classroom. Through this approach, the paper seeks to critically consider the omnipresent socio-political agendas and landscapes of compulsory schooling in each nation that influence the construction of geography education (Morgan, 2019), using the context of migration as a defining social dimension of contemporary global society. As a conceptual paper, its focus is to introduce, and examine, these debates as important considerations for geography education in schools. The practical application of 
geocapabilities and transculturalism as transformative strategies is not within its scope, but indicates a worthwhile direction for future research.

As reflected in Tilly's quotation above, people's geographies and imaginations of the world vary significantly, but it is important to acknowledge that all geographies and voices matter. This is because we all shape, and are all shaped by, our worlds and the spaces and places we exist within and contribute to. The Christchurch shootings in March 2019 provided a tragic and extreme reminder of both the complex relationships between individuals and the place/spacetime within which they exist, and of the potential consequences of social distance and feelings of exclusion. For these reasons, people's experiences and imaginations of the world are areas of contemporary concern in both the academic discipline of geography and society more broadly. In that context, Tilly's narrative, which is a personal perception of the city and country in which she lives, can be received as an expression of, and response to, the wider social and political context (Cameron, 2012). Although Tilly's is just one voice, her narrative can be read as being representative of London as a 'world city' (see Massey, 2008), a place that is continuously under construction and being socially (re)produced (Author 3, forthcoming) in part through migration. For Massey, the evolution of London (or any place) raises questions of identity that are pivotal in examining the politics of place. These questions of identity are pertinent both to the city itself, and also to the people(s) who live in London and their relationships to it. For Tilly, London is a multicultural city that on a surface level appears to be socially cohesive, but which hides stories of social exclusion and experiences of a 'friction of distance' (see Harvey, 1990) from the place in which the person lives. In a similar vein, some young people in the outer suburbs of Melbourne, Australia, are also finding it difficult to establish a personal space in newly built urban areas (Robertson, Montuoro, \& Burston, 2019). 
This paper is divided into three main sections. Firstly, we offer a brief overview of the three concepts that underpin the paper: migration, geocapabilities and transculturalism. Secondly, the paper offers a comparative examination of how migration is treated in the Geography national curricula of Australia and England, with specific exploration of the degree to which they reflect geocapabilities and a transcultural approach in supporting and enabling teachers and young people to use Geography as a discipline to examine the complex and multifaceted nature of migration. For ease of comparison, the analysis will be limited to the compulsory years of secondary schooling; Key Stage 3 in England and Years 7-10 in Australia. Differences and similarities in the two national contexts are considered throughout. The paper concludes by arguing that geography teachers and educators should actively consider a geocapabilities and transcultural lens when exploring complex social geographies such as migration. In doing so, we contend that these dual concepts can support and empower young people in their academic and social navigation of the complexities of this day and age.

\section{B The Underlying Concepts}

\section{$1 \quad$ Migration - a defining feature of this day and age?}

At the heart of Tilly's quote at the start of this paper is her perception that migration is changing London and the UK by making it more multicultural. She expresses the belief that, 'even though people say London is so multicultural, yeah maybe they're right, but deep down no one really accepts you' (Author 3, forthcoming). Her comments can be interpreted as her expressing of concerns about the creation of a landscape imbued with social exclusion, which is hidden by surface level social pleasantries. This example highlights that Tilly, like all people, 
has relationships with and to place(s). People have emotional responses and connections to place, construct and develop them, socially (re)produce them, and they sometimes leave them. This recognition, and study, of people's relationships with place is nothing new to geography; indeed, it is a significant area of research and discourse in the academy (see for example, Cresswell, 1996; Jackson, 1992; Massey, 2008). A fundamental area of this discourse is migration, which is defined by Gregory et al. (2009, p. 462) as being 'the residential movement of an individual, family or group from one place to another'.

Migration is argued by Castles et al. $(2014$, p.1) to be 'one of the most emotive subjects in contemporary societies', especially when it results in ethnic and racial diversity. Its power and potential to fundamentally alter the socio-cultural, economic and political fabric of societies, has made migration a source of much debate, both in the academy and in everyday sociopolitical discourse. These debates include recognition of the benefits of migration (for example, through social and economic remittances or attracting a workforce to a place), as well as the political acts and decisions that attempt to stop migration. Donald Trump's (2016) presidential campaign promise to build a wall between the United States of America and Mexico is a recent infamous example of this. These examples highlight that migration can be viewed from two different geographic perspectives: namely, geographies of migration (movements of people we can map with quantitative demographic data), but also the impacts that migration has on the places that people move to and leave behind, which are often more qualitative in nature. In addition to this, these geographies are experienced and imagined in different ways by migrants and others, including the children we teach. Examining all of these elements is fundamental to exploring migration. 
We now move on to considering how we might use the teaching of geography in schools to explore migration in ways that pay attention to these complex interactions of people, places and culture. We recognise that the child's experiences and imaginations (which might be both individual and shared) are key to the teacher's decision-making about exactly what and how to teach about migration. However, a balance of attention to geography (disciplinary) knowledge), the child and teaching methods is needed, if the teaching of culturally and values laden topics, like migration, are to be transformative for the individual. We argue that the

notions of geographic 'capabilities' (geocapabilities) and transculturalism both provide conceptual frameworks that can act as a foundation for a geography education that revitalises student attitudes to their lives, and we conclude by suggesting that cultural understanding through its transcultural construction could be a helpful way of evaluating the transformative potential of a geocapabilities approach to school geography. Before addressing that conclusion, the next two sections will explain what we mean by 'geocapabilities' and 'transculturalism' as the conceptual bases of the discussion.

\section{Geocapabilities - a progressive view of geographical knowledge}

Human capabilities theory originates in welfare economics (Sen, 1995 and Nussbaum, 2011) and describes a person's capabilities to access each of the 'functionings' of a human 'being', such as being: healthy; able to live with others; able to reason, able to participate in political debate and so forth. There can be obstacles to full functioning; for example, having no access to clean water (preventing good health), or no access to knowledge (preventing reasoning and participation). Capability has been described as: 'the freedom to enjoy valuable functionings' (Boni and Walker 2013, p. 3) and can be thought of as the freedom to make choices in life. 
Enabling this freedom is the 'empowerment' dimension of human development (Lambert, Solem and Tani, 2015, p.2), and it is here that education has a key role.

'Geocapabilities' is a project to connect human capabilities to the discipline of Geography by asking 'in what ways is human development diminished if geography is absent or poorly provided for in formal education?' (Lambert, Solem and Tani, 2015, p. 2). If geographical knowledge (specialised in the discipline, bounded and distinct from 'everyday' knowledge) is needed for a human being to be capable of reasoning and participation in significant political debates, then geography and capabilities can be connected as geographic-capabilities (geocapabilities) and geography can be shown to be an essential part of an 'empowering' education.

Geocapabilities seeks to describe 'a progressive and convincing discipline-oriented view of geography in education for this day and age' (Lambert, Solem and Tani, 2015, p. 5). This disciplinary emphasis places knowledge at centre stage and, in the conceptual development phase of the Geocapabilities project, three underpinning knowledge principles were adopted: 'powerful disciplinary knowledge' (PDK); a 'future 3' curriculum (Young and Muller, 2010, Lambert and Young, 2015); and curriculum making (GA, 2009, Lambert and Morgan, 2010). There is not scope to explain these three principles in detail here, but each is significant for the teaching of migration in ways that, later in this paper, we connect to the potential of geocapabilities for transcultural understanding.

PDK can allow children to think, analyse and 'know' the world in ways they cannot through 'everyday' knowledge. It is systematic and has strong boundaries - the disciplines having been formed and tested by a long history of research and scholarship. Describing what PDK 'looks 
like' in ways that may help geography teachers and teacher educators is challenging, but there have been attempts to do so, notably by Maude (2016, 2018) and Roberts (2017). These break down 'powerful knowledge' into ways that we might better identify when geographical knowledge is transformative for school children and so offer ways to look at how we might teach about complex topics like migration.

A 'future 3 curriculum' (F3) (Young and Muller, 2010) gives subject knowledge its power to be 'relevant' for education 'in this day and age'. This is a forward-looking, progressive view of knowledge, which 'frees us from geographical knowledge assumed to be absolute, given, and pre-existing' (Lambert, Solem and Tani, 2015, p. 2). Such a fixed or backward-looking knowledge is a 'future 1' curriculum. At the opposite end of the spectrum is the 'future 2' curriculum, where subject boundaries are weak or lost altogether and the curriculum becomes a mere vehicle for skills and competencies. An F3 curriculum means teachers engaging with recent developments in academic geography while balancing their teaching to their students' particular needs and local situations as well the social issues of the times. F3 curriculum thinking is therefore connected to 'powerful' ways of teaching migration which resonate both with education for intercultural understanding and with the notion of transculturalism.

The third key principle is 'curriculum making' (CM) (see Figure 1). As a 'curriculum maker', the geography teacher accepts a curriculum leadership role and responsibility (Author 2, 2015). In order to decide which topic to teach and how they will teach it, the teacher needs clear educational aims and purposes, balancing their attention between their students' experiences, the subject and teaching choices (Lambert, 2009, p. 124). In this sense, migration is a particularly rich topic and it is easy to imagine many alternative ways of teaching it, with different children, in different places and times. 


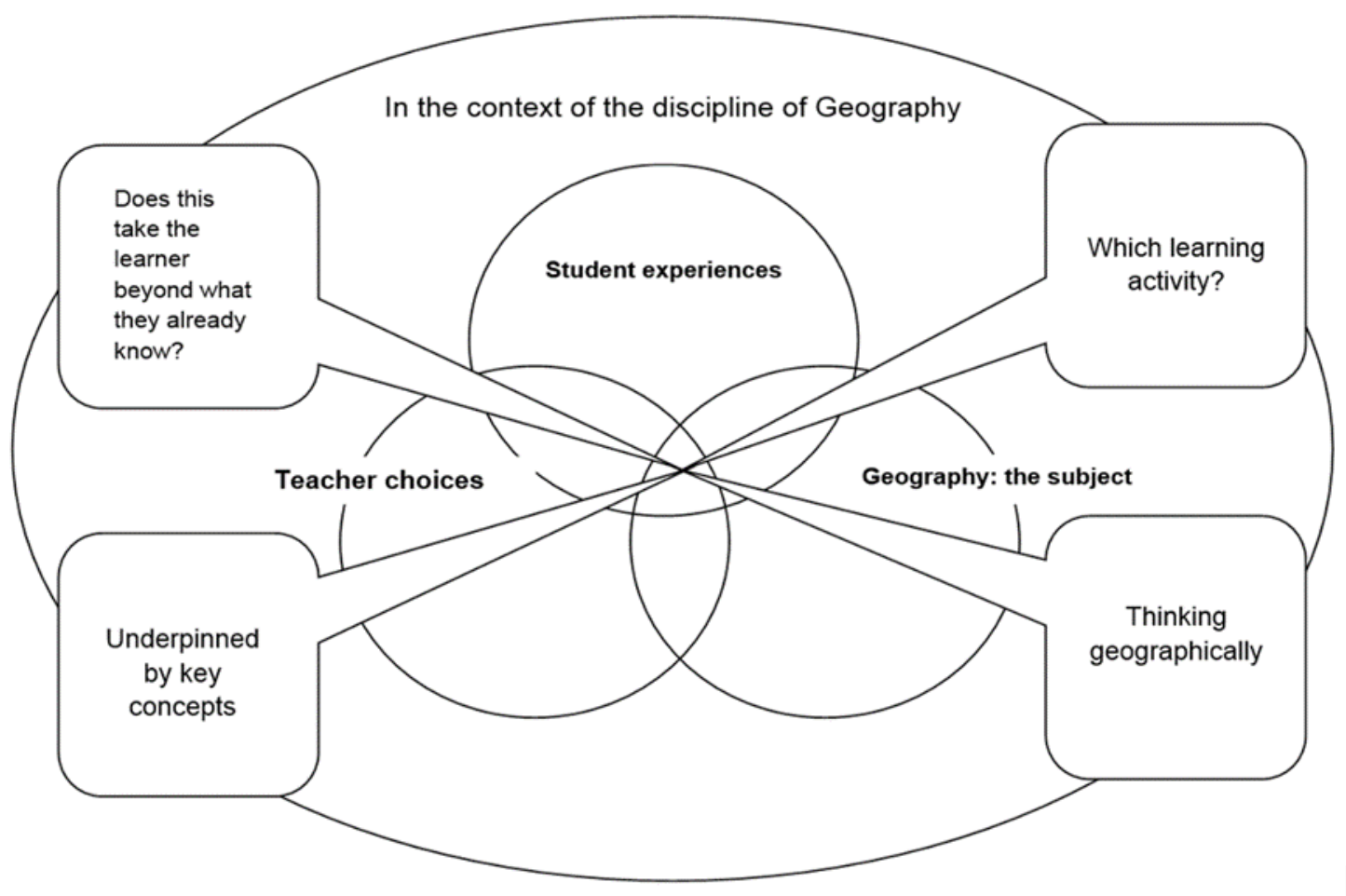

INSERT FIGURE 1]

Figure 1 'Curriculum making', based on the description in the Geographical Association's manifesto (Geographical Association, 2009) and discussed by Lambert and Morgan (2010)

\section{$3 \quad$ Transculturalism}

The educational field of specific teaching for cultural understanding is one that can be largely conceived as having its origins with the formation of the United Nations after World War Two (Author 1, in press, 2020). In brief, the determination to find a means of diminishing the possibility of future global conflict through such an organisation that promoted, facilitated and enabled global co-operation included a belief that education in and understanding of the ways in which different people lived and perceived their worlds was central to that aim. Initially, the focus was learning about different cultures, and this became substantiated in the early 1960s through the notion of multicultural education. By the 1980s, there was a paradigm shift towards 
intercultural education as the next stage of cultural learnings. Although the nature and scope of both these terms remain highly contested (Dervin, 2014; Kymlicka, 2003), multiculturalism is essentially concerned with the building of knowledge about the different ways in which people conduct their lives whereas interculturalism is generally taken to refer to a focus on how people from different cultures communicate, but with a particular focus on the ways in which power imbalances between multiple cultures within a society can affect that communication and the nature of societal relationships.

However, as mentioned in the earlier rationale for this paper, education must remain significant to those who are being taught. Ipso facto, educational concepts and practices must evolve as a society shifts in character. In that regard, the difficulty with both multicultural and intercultural education is that, conceptually, they are increasingly unable to address the culturally complex character of contemporary society, which itself has direct connections to modern patterns of migration. Both concepts were developed in times prior to the contemporary phase of globalisation, which is generally seen to commence with the adoption of global internet in the early 1990s (Vertovec, 2009), and both are inherently based on the principle that cultural difference is a barrier to be overcome. This is reflected in the number of Western European countries that do not collect population data based on ethnicity in the name of promoting national cohesion, in contrast to the UK and Ireland, who collate such data with the aim of taking positive action against the demonisation of the 'Other' (Escafre-Dublet \& Simon, 2012). And yet, the $21^{\text {st }}$ century has seen the existence of cultural diversity in society to be so endemic that the existence of difference must now be seen as the norm, and not an exception.

The rapid advances in the availability and affordability of communications technology, especially in transport, have had a dramatic impact on global cultural demographics. Population 
movement has been particularly affected as the concept of migration is no longer as permanent a phenomenon as it once was. There is now a substantial group of people who live in one place, but work in others as they are not held back by geographical friction of distance. International migration is now not as final an act as it was in the past and connections to people in other geographical locations are easier to maintain. People are more likely to have multiple connections and the meeting and mixing of people with different cultural heritages is now a feature of modern society, not an exception (Rizvi, 2009).

In order to provide a more realistic framework for the teaching of cultural understanding in the $21^{\text {st }}$ Century, the notion of transculturalism has been presented as a necessary progression, a stage that builds on the original theme of multiculturalism and its more recent cousin, interculturalism (Author 1, 2016a). A transcultural attitude builds on multi- and interculturalism by seeing cultural diversity as the societal norm, not as an exception that needs to be addressed in the interests of homogeneity. Consequently, it also considers migration, along with its contingent frequency of cultural meeting and mixing, to be an accepted part of the rhythm of modern existence (Author 1, In Press, 2020). This openness and expectation of difference makes the transcultural concept particularly relevant to Geography and geography education because of the inherent holistic nature of geographical inquiry (Author 1, 2018a, 2018b). By its nature, geographical inquiry considers all physical and human phenomena in a region as being important potential data; there are no prior assumptions as to what is different or less important. Difference is expected as part of the norm and nothing is precluded, reflecting an attitudinal approach that accepts the reality of difference as important, but not as an outlier. 
The paper now moves on to critically examine how geography education in England and Australia represents and explores these fields, reflecting on the value of geocapabilities and transculturalism as lenses of educational interpretation.

\section{Migration in Geography Education Curricula: Australia and England}

Table 1: Migration as an Element in the Australian Curriculum: Geography Years 7 -10]

\begin{tabular}{|c|c|c|}
\hline $\begin{array}{c}\text { Overview } \\
\text { Year 8: Semester Two } \\
\text { Changing Nations }\end{array}$ & Content Descriptions & Content Elaborations \\
\hline $\begin{array}{l}\text { the changing human geography } \\
\text { of countries, as revealed by } \\
\text { shifts in population distribution. }\end{array}$ & $\begin{array}{l}\text { Differences in and urban } \\
\text { settlement patterns between } \\
\text { Australia and the United } \\
\text { States of America, and their } \\
\text { causes and consequences }\end{array}$ & $\begin{array}{l}\text { researching the causes of urban } \\
\text { concentration in Australia and the } \\
\text { United States of America (for } \\
\text { example... migration) }\end{array}$ \\
\hline $\begin{array}{l}\text { redistribution of population } \\
\text { resulting from internal } \\
\text { migration is examined through } \\
\text { case studies of Australia and } \\
\text { China }\end{array}$ & \multirow{3}{*}{$\begin{array}{l}\text { Reasons for, and effects of, } \\
\text { international migration in } \\
\text { both Australia and China }\end{array}$} & $\begin{array}{l}\text { identifying and explaining the main } \\
\text { types, patterns and trends of internal } \\
\text { migration in Australia }\end{array}$ \\
\hline $\begin{array}{l}\text { contrasted with the way } \\
\text { international migration } \\
\text { reinforces urban concentration } \\
\text { in } \\
\text { Australia }\end{array}$ & & $\begin{array}{l}\text { examining the effects of resource } \\
\text { development on employment growth in } \\
\text { both the resource regions } \\
\text { and the cities, and on internal migration } \\
\text { in Australia }\end{array}$ \\
\hline & & $\begin{array}{l}\text { identifying and explaining the patterns of } \\
\text { temporary and permanent internal }\end{array}$ \\
\hline
\end{tabular}




\begin{tabular}{|c|c|}
\hline & $\begin{array}{l}\text { migration in China and the effects on } \\
\text { the places of origin and destination }\end{array}$ \\
\hline & $\begin{array}{l}\text { examining the role of labour migration } \\
\text { in the urban development of China (for } \\
\text { example, the growth of } \\
\text { Shenzhen, Guangdong Province) }\end{array}$ \\
\hline $\begin{array}{l}\text { Reasons for, and effects of, } \\
\text { international migration in } \\
\text { Australia }\end{array}$ & $\begin{array}{l}\text { identifying and explaining the main types } \\
\text { and patterns of international migration } \\
\text { (for example, } \\
\text { permanent migration, temporary labour } \\
\text { migration, student migration, forced } \\
\text { migration (including } \\
\text { refugees) and family reunion) }\end{array}$ \\
\hline
\end{tabular}

Table 2: $\quad$ Migration as an Element in the English National Curriculum: Geography Key Stage 3]

\begin{tabular}{|c|c|}
\hline $\begin{array}{l}\text { Type of } \\
\text { Knowledge }\end{array}$ & References to Migration \\
\hline Locational & $\begin{array}{l}\text { extend their locational knowledge and deepen their spatial awareness of the world"s } \\
\text { countries... focusing on their environmental regions, including polar and hot deserts, } \\
\text { key physical and human characteristics, countries and major cities }\end{array}$ \\
\hline Place & $\begin{array}{l}\text { understand geographical similarities, differences and links between places through } \\
\text { the study of the human and physical geography of a region in Africa and a region in } \\
\text { Asia }\end{array}$ \\
\hline $\begin{array}{c}\text { Human and } \\
\text { Physical }\end{array}$ & $\begin{array}{l}\text { understand, through the use of detailed place-based exemplars at a variety of scales, } \\
\text { the key processes in: ... }\end{array}$ \\
\hline
\end{tabular}




\begin{tabular}{|l|l|}
\hline & $\begin{array}{l}\text { human geography relating to: population and urbanisation; international } \\
\text { development; economic activity in the primary, secondary, tertiary and quaternary } \\
\text { sectors; and the use of natural resources }\end{array}$ \\
\hline $\begin{array}{c}\text { Geographical Skills } \\
\text { and Fieldwork }\end{array}$ & \\
\hline
\end{tabular}

As illustrated by Tables 1 and 2, there is a strong contrast how migration is addressed in the Geography national curriculums of Australia (Australian Curriculum Assessment and Reporting Authority [ACARA], 2019) and England (Department of Education, 2014). To a large degree, these differences are the result of the variances in the philosophical and structural framework of both curriculums. The Australian Curriculum has specific content, skills and capabilities listed for each learning area in each of the four years of mandatory secondary education (Years 7-10). In the case of the Geography domain, which falls under the learning area of Humanities and Social Sciences (HASS), this takes the form of two strands, that of geographical knowledge and understanding, and a second in geographical enquiry and skills. The first strand, which sets out what is to be taught, is divided into two semester units per year level. Each semester unit is divided into two halves; a study that is predominantly physical geography and another that is primarily focused on human geography. The content and skills to be taught in each unit are specified in a series of content descriptions, which are fleshed out by examples of elaborations, which are illustrative only and can be adapted by individual teachers. Aims and rationales are listed for each level in the hierarchy of the domain framework, as are a series of geography achievement standards for each level. Across all learning areas, the teaching of seven general capabilities must also take place, which include the learning of intercultural understanding, personal and social skills, and ethics. 
However, the detail provided in the Australian Curriculum is not evident in the Geography national curriculum in the England. Instead, a set of broad achievement expectations in knowledge(s), understandings and skills, framed under four major types of knowledge (see Table 2), are provided. The UK has no single national curriculum (education in England, Scotland, Wales and Northern Ireland are administered separately) and so here we consider migration in the English school curriculum at 'Key Stage 3' (KS3 - the junior high school years, ages 11-14, and where Geography is a compulsory subject area). Migration is notable by its absence in the national curriculum programme of study at KS3. By comparison, migration is explicitly mentioned in the Australian counterpart. Aside from references to human geographical phenomena such as cities, population and urbanisation, the English curriculum does not contain any mandatory study of the concept of migration. In contrast, the Australian framework sees migration listed as one of the major topics to be studied under the Year 8 Semester Two theme of Changing Nations (Table 12). In particular, there is a focus on the study of both internal migration within Australia, China and the USA, as well as international migration into Australia.

This apparent lack of specific detail in the English context is partly a function of the paring down of the prescribed national curriculum to its 'bare bones'. The whole content of the KS3 geography national curriculum, for study over up to three years, is just two pages long, with the principle being that teachers should develop the detail of KS3 content at the local school level. This is ostensibly designed to hand more responsibility for detailed curriculum content decisions to teachers, away from centralised control. Hence, the latest national curriculum was accompanied by the abolition of the quasi-autonomous, yet centrally funded, Qualifications and Curriculum Authority (QCA). Although the shift provided the opportunity for more 
teachers to take on the responsibility of 'curriculum making' and has been thus welcomed, it has been highlighted that, in order for teachers to be properly equipped for this role, they require sufficient initial teacher education and support (Author 2, 2015).

However, there is a tension between the current English Geography national curriculum (GNC) as intending to give teachers responsibility for curriculum design, whilst at the same time specifying some topics, and omitting others. For example, topics referred to specifically in the GNC include the 'Middle East', 'glaciation' and 'soil' (DFE, 2014), but not 'migration' or 'sustainable development', even though these can be argued to be equally valid substantial fields of geographic study. The previous iteration of the English GNC, which applied in 20072013, avoided specifying geographical topics. Rather, it nominated only geographical concepts, processes of learning geography and broad areas or 'ranges' of content. By shifting to the current GNC, which includes a list of specific content, the education department of the time (steered by a Conservative Secretary of State for Education) may have encouraged some teachers toward 'future 1' curriculum thinking. This is because 'future 1' sees geography as a list of fixed content, less open to an inclination to interpret Geography in a progressive way, such as looking at how geographical concepts can be applied in light of recent developments in the discipline alongside changes to children's world view. Our point here is that whilst the current GNC for England can be interpreted by the critical and careful teacher to design a future 3 geography curriculum, it may have steered less critical teachers toward future 1 thinking.

Furthermore, the absence of explicit reference to migration may indicate a prioritising of content as a consequence of apolitical decision or mind-set of England's Department of Education at the time that the national curriculum was set out for teaching from 2014. So, for example, required content includes 'the Middle East', 'glaciation' and 'soil' (DFE, 2014) but 
not 'migration'. The risk here is that a 'future 1' curriculum could be adopted, if teachers are not encouraged to interpret geography in the national curriculum in a progressive way for a 'future 3'.

In practice, migration at KS3 in England is overwhelmingly taught as just a few lessons within 'population' and/or 'urbanisation' unit (these are named in the KS3 curriculum). In an overarching statement of curriculum content, the KS3 national curriculum states that children at KS3 should be taught to:

'understand the processes that give rise to key physical and human geographical features of the world, how these are interdependent and how they bring about spatial variation and change over time,

DFE (2014)

It is difficult to imagine not teaching about migration at KS3 given its significance as a human process affecting all people and places in the UK to some extent. There is scope and opportunity to do so. However, school geography in England is under great pressure from the accountability and performativity that affects schools and teachers, and this can distract teachers from fully engaging in 'curriculum making' geography at KS3 (Author 2, 2019). Migration at KS3 is generally built around the 'push and pull' model with a focus on rural - urban migration in lower income countries and counter-urbanisation and re-urbanisation in the higher income countries.

In the older years (14-16 and 16-18) where students can opt in or out of geography exam courses at school (about a third of children do not study geography beyond KS3) there are more 
detailed 'specifications' and there is an emphasis on 'issues', 'challenges' and 'globalisation'. One 16-18 specification specifies 'international migration: refugees, asylum seekers and economic migrants' (AQA, 2016). But at KS3 (11-14-year-old children), migration can be difficult to teach in ways that engage with developments in the discipline such as the 'mobilities' turn and concepts of 'home' and identity, which are now significant areas of university geography research. This is not to say that the most dedicated geography teachers are not 'making' a geography curriculum that resonates with the times, but it is hard to do in the current, pressurised school climate (Author 2, 2019).

In terms of the development of geocapabilities, it would appear that the Australian framework offers more specific incentive and direction for teachers to encourage '... young people to think beyond themselves and their everyday encounters of people' (Geocapabilties, 2016). These instructions are certainly more directed in terms of the what, how and why or migration patterns and the impact that these have on the human and physical world. Nonetheless, these instructions are primarily in the context of the description and explanation of patterns. As argued elsewhere (Author 1, 2016b), one of the key failings of the current Australian Curriculum: Geography framework is that it does not promote or facilitate one of the key facets of geographical enquiry that makes it transformative as a discipline (Author 1, 2018a); its focus on the prediction and creation of an ideal or improved situation, based on a study of the present.

This notion of Geography as a 'powerful' discipline (Maude, 2018; Young, 2006) is at the heart of what the notion of geocapabilities encompasses (Uhlenwinkel, Béneker, Bladh, Tani, \& Lambert, 2017); giving young people the learnings that enable them to not only be aware of the wider implications of their studies, but to them have the knowledge, skills and motivation to take that perception into their personal lives. Geocapabilities can provide a framework to 
support teachers in their curriculum making and, as we now conclude this has the potential to be transformative by enabling teachers to apply a transcultural lens in the geography classroom.

\section{Transculturalism, geocapabilities and the power of transformation}

Migration in geographical education tends to draw heavily on demographic statistics. Whether the migration is intra-national at a variety of scales, or international in scope, school-based study on migration tends to start with the patterns revealed by the data. Educationally, however, if removed from tangible human stories, a focus on statistics, even initially, runs the risk of excluding students who struggle with numeracy or graphicacy or who lack the cultural capital to support engagement and motivation. In England, the possible KS3 focus on issues such as economic migrants and refugees, and the similar Australian focus on economic aspects of internal and international migration, lack any clear connection to the personal world(s) of the student, unless they are themselves refugees or economic migrants; in other words, the migration topics lack significance to those who are being taught.

It is in cases such as these that an approach to geographical education that incorporated principles that are embodied in geocapabilities and/or transculturalism can be more effective and engaging because these concepts both enable students to place the isolated study of demographic statistics into a social context that they can relate to. In the case of both geocapabilities and transculturalism, this would see a migration study beginning, not with the 
statistics of migration or a disembodied theoretical model, but with the socio-cultural and political contexts that have led to such overall trends; the ways in which the cultural character(s) of all societies have changed across space-time by the actions of people migrating. The study of current migration trends is therefore reconfigured into a study of modern substantiations of older themes, in which migration is not a phenomenon of difference at all, but the recurrence of long-exemplified trends. A geocapabilities approach would explore the socio-economic-political forces that created the modern patterns of migration, thereby centring the discussion on how societies have been changed by migration and the implications for wider societal impact. The study of migration, through either lens, thus becomes an exploration of possible past, current and future societal transformations, and not a dry, disconnected study of demographic statistics that has no social context.

The latest stage (Phase Three) of the Geocapabilities project, which runs from 2018-2020 (Geocapabilities 3, 2019) is beginning to produce some empirical evidence to show how the curriculum can become more significant for children when a progressive view of 'powerful' geographical knowledge is embraced by geography teachers. Geocapabilities 3 is working with teachers in challenging school contexts in several European countries, teaching less privileged children, often where migration is a sensitive issue. The teachers engage with academic geographers (migration specialists) and teacher educators to develop a 'future 3' curriculum of powerful knowledge (geographical knowledge about migration of significance for their current and future lives). One insight, from the early stages of the project, is that teachers, working collaboratively in this way, have devised tools that allow them to interpret abstract concepts (PDK, future 3, curriculum making and 'significance') in ways that become practical tools, to help plan and evaluate the powerful geographical knowledge of migration taught and learned in the school classroom. One example of this is a simple template devised to prompt teachers' 
thinking when planning and to support their evaluation of migration as PDK for children (see Table 3). It may be that, in examining the notion of 'significance' for the child's future, the teacher can identify the transformative power of PDK. As the Geocapabilities 3 project is in its early stages, there is no data, at present, to illustrate such transformative potential from the teaching of migration through geography, but it is hoped to be able to do so by the end of the project.

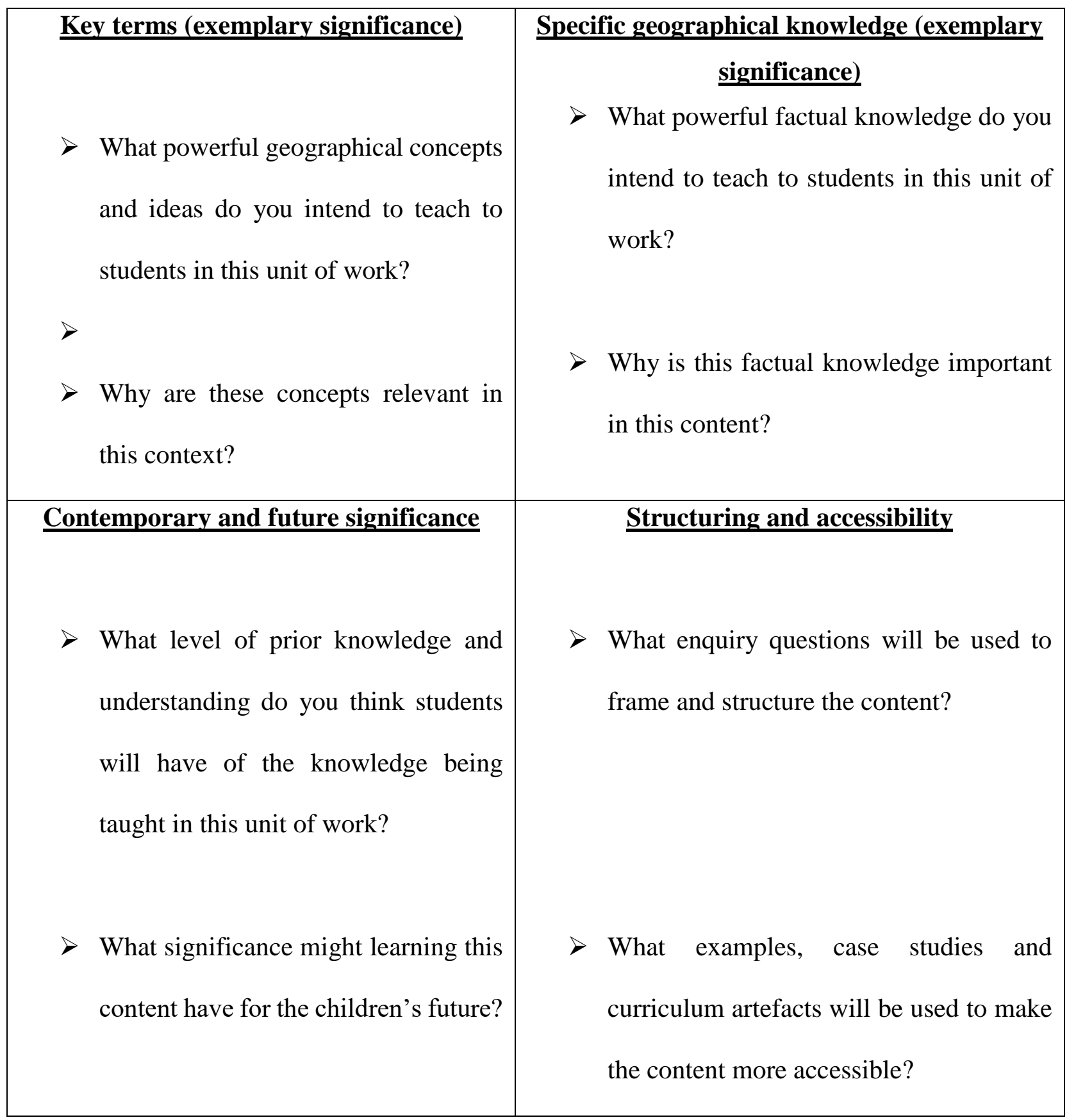


Table 3 Powerful geographical knowledge: a teacher planning tool (Reproduced courtesy of Geocapabilities 3 project)

The notion of transculturalism has not yet been fed into the Geocapabilities 3 project. However, the success of teachers in developing practical tools which support a progressive knowledgebased geography curriculum, suggests to us that transculturalism can be a helpful lens for planning and evaluating powerful geographical knowledge. Planning to teach the geography of migration through a transcultural lens will encourage the use of multi-layered human stories that transcend binaries of 'them and us' and overcome an exaggerated separation of one culture from another. Evaluation of the significance of the geographical knowledge of migration for the child, now and in the future - that is, the powerful knowledge - can be supported by considering how far the child has progressed from a multicultural and intercultural way of thinking, to a transcultural understanding. The stage is now set for further empirical work that could examine the practical implications of our proposition that transculturalism and geocapabilities can be connected to support geography teachers in productive, transformative ways.

\section{References}

Australian Curriculum Assessment and Reporting Authority [ACARA]. (2019). The Australian Curriculum: Geography. Sydney: Australian Curriculum, Assessment and Reporting Authority, Retrieved from https://www.australiancurriculum.edu.au/f-10curriculum/humanities-and-social-sciences/geography/ 
Biddle, D. O. N. (1999). Geography in Schools. Australian Geographer, 30(1), 75-92. doi:10.1080/00049189993774

Bliss, S. (2006). Forum: Geography and Geographical Education in New South Wales, Australia. International Research in Geographical and Environmental Education, 15(2), 149-158. doi:10.2667/irgee192a.0

Boni, A., and M. Walker, eds. (2013) Human development and capabilities: Reimagining the university of the twenty-first century. London and New York: Routledge.

Butt, G., \& Lambert, D. (2014). International perspectives on the future of geography education: an analysis of national curricula and standards. International Research in Geographical and Environmental Education, 23(1), 1-12. doi:10.1080/10382046.2013.858402

Author 1. (2015).

Author 1 (2016a)

Author 1 (2016b).

Author 1 (In Press, 2020).

Author 1 (2018a).

Author $1(2018 b)$.

Conolly, G. (2000). Promotion of Geography in Australia: An Unfinished Story. International Research in Geographical and Environmental Education, 9(2), 160165. doi:10.1080/10382040008667644

Department of Education (2014) National curriculum in England: geography programmes of study. Online content, last accessed 8.07.19. https://www.gov.England/government/publications/national-curriculum-in-englandgeography-programmes-of-study 
Dervin, F. (2014). Towards post-intercultural teacher education: analysing 'extreme' intercultural dialogue to reconstruct interculturality. European Journal of Teacher Education, 38(1), 71-86. doi:10.1080/02619768.2014.902441

Escafre-Dublet, A., \& Simon, P. (2012). Ethnic Statistics in Europe: The Paradox of Colourblindness. In A. Triandafyllidou, T. Modood, \& N. Meer (Eds.), European Multiculturalisms: Cultural, Religious and Ethnic Challenges (pp. 213-237). Edinburgh: Edinburgh University Press.

Geocapabilties. (2016). Home. Retrieved from http://www.geocapabilities.org/geocapabilities-2/

Government of United KIngdom. (2019). National curriculum in England: geography programmes of study. Retrieved from https://www.gov.England/government/collections/national-curriculum

Author 3 (unpublished, forthcoming)

Hutchinson, N. (2006). Geography in Australian Schools: A View from the AGTA Chair. International Research in Geographical and Environmental Education, 15(2), 193198. doi:10.2167/irgee192i.0

Klafki, W. (2000) 'Didaktik analysis as the core of preparation of instruction'. In Westbury, I., Hopmann, S. and Riquarts, K. (eds) Teaching as a Reflective Practice: The German Didaktik tradition. London: Routledge, 139-60.

Kymlicka, W. (2003). Multicultural States and Intercultural Citizens. Theory and Research in Education, 1(2), 147-170.

Lambert, D. (2009) 'A Different View’, Geography 94, 2, pp. 119-125.

Lambert, D, Solem, M. \& Tani, S. (2015) ‘Achieving Human Potential Through Geography Education: A Capabilities Approach to Curriculum-making in Schools', Annals of the Association of American Geographers, 105, 4, pp. 723-735. 
Maude, A. (2016) 'What Might Powerful Geographical Knowledge Look Like? in Geography 101(2) pp.70 -76

Maude, A. (2018). Geography and powerful knowledge: a contribution to the debate. International Research in Geographical and Environmental Education, 27(2), 179190. doi:10.1080/10382046.2017.1320899

Author 2. (2009)

Author 2. (In Press, 2019).

Author 2 (2015)

Morgan, J. (2014). Fortunate inhabitants? Challenges for school geography in New Zealand. International Research in Geographical and Environmental Education, 23(1), 53-63. doi:10.1080/10382046.2013.858440

Nussbaum, M. (2011). Creating Capabilities: The Human Development Approach. Cambridge, MA: Harvard University

Rizvi, F. (2009). Towards cosmopolitan learning. Discourse: Studies in the Cultural Politics of Education, 30(3), 253-268. doi:10.1080/01596300903036863

Roberts, M. (2017) 'Geographical education is powerful if...' Teaching Geography, 42, 1, pp. 6-9.

Robertson, M., Montuoro, P., \& Burston, M. (2019). Overcoming obstacles on the peri-urban fringe: young people making new geographies. Geographical Research, 57(2), 151163. doi:10.1111/1745-5871.12315

Semple, S. (2005). Reflections on Geography: The Worst Taught Subject? A View from Canada. International Research in Geographical and Environmental Education, 14(1), 77-79. doi:10.1080/09500790508668335

Sen, A. 1995. Inequality reexamined. Oxford, ENGLAND: Oxford University Press. 
Uhlenwinkel, A., Béneker, T., Bladh, G., Tani, S., \& Lambert, D. (2017). GeoCapabilities and curriculum leadership: balancing the priorities of aim-based and knowledge-led curriculum thinking in schools. International Research in Geographical and Environmental Education, 26(4), 327-341. doi:10.1080/10382046.2016.1262603

Vertovec, S. (2009). Transnationalism. Milton Park, Abingdon: Routledge.

Walker, M. (2006) 'Towards a capability-based theory of social justice for education policy making', Journal of Education Policy, 21(2): pp. 163-185.

Young, M. (2006). Curriculum Studies and the Problem of Knowledge. In H. Lauder, P. Brown, J.-A. Dillabough, \& A. H. Halsey (Eds.), Education, Globalization, and Social Change (pp. 734-741). New York: Oxford University Press.

Young, M. \& Muller, J. (2010) 'Three Educational Scenarios for the Future: lessons from the sociology of knowledge', European Journal of Education, 45, 1, pp. 11-26. 